SINAI Journal of Applied Sciences

\title{
IMPROVING PRODUCTIVITY OF WILD MINT (Mentha longifolia L.) PLANTS BY USING HUMIC ACID UNDER SALINE WATER IRRIGATION CONDITIONS
}

\author{
Ahmed, A. El-Alakmy ${ }^{\text {* }}$, H.S.M. Hassan ${ }^{2}$, M.Y.M. Badawy ${ }^{1}$ and M.A.M., Ali ${ }^{2}$ \\ 1. Dept. Med. and Aromatic Plants, Cent. Des. Res., El-Mataria, Cairo, Egypt. \\ 2. Dept. Plant Prod., Fac. Environ. Agric. Sci., Arish Univ., Egypt.
}

\begin{abstract}
This study was carried out on Mentha longifolia L. Fam. Lamiaceae (Labiatae) at the Farm of North Sinai Research Station, El-Sheikh Zwaid city during the two successive seasons of 2014/2015 and 2015/2016 to improve growth, productivity and oil production as well as chemical composition of Mentha longifolia L. plant under North Sinai conditions by using humic acid (0,3 and 6 Litre.fed $\left.^{-1}\right)$ under different levels of saline water (Tap water, 2048 ppm and $4224 \mathrm{ppm})$. Generally the highest values of vegetative growth parameters, oil production and chemical composition were obtained by using tap water and fertilizing with humic acid at 6 l.fed $^{-1}$ in first experiment. But under arid and semi-arid conditions like North Sinai Governorate, humic acid could offer an economical and simple application to salt sensitive plant, it can be use saline water at $2048 \mathrm{ppm}+$ humic acid at 6 1.fed $^{-1}$ to decrease water salinity stress without decreasing in yield or oil production of Mentha longifolia L.
\end{abstract}

Key Words: Saline water, humic acid and Mentha longifolia L.

\section{INTRODUCTION}

Mentha longifolia L. Hudson is an aromatic perennial herbs $40-120 \mathrm{~cm}$ hight with musty scent and belongs to Lamiaceae (mint family) and grows mostly in semishady places on moist soils (Sher and Khan, 2007). Definition of plant tolerance to salinity may change depending on the agronomic or ecological importance of the plant. Within an agronomic context, plant salt tolerance is referred to as the capability of a plant to withstand the effects of salt concentration in the root-zone or within the plant with none or minimum reductions in growth or yield (Maas, 1990; Shannon and Grieve, 1999). From the ecological perspective, plant tolerance to salinity is the capability of plant to complete its life cycle in saline environment (Parida and Das,

\footnotetext{
* Corresponding author: Tel.: +201228034124

E-mail address: ahmedelalakmy@yahoo.com
}

2005). Reduction in cell elongation and division in leaves reduces their final size, resulting in a decrease in leaf area (Matsuda and Riazi, 1981; Alarcon et al., 1993 and Munns and Tester, 2008). Leaf area reduction could be caused by the decrease in turgor in the leaves, as consequence of changes in cell wall properties or reduction in photosynthetic rate (Franco et al., 1997). In North Sinai, Egypt, water irrigation of the Mediterranean Region characterized by high salinity and low quality. Salinity inhibits plant growth and productivity by a range of mechanisms; include osmotic effects, direct ion toxicity and interference with the uptake of nutrients (Shannon et al., 1994).

The major functional groups of humic substance include carboxyl, phenolic 
hydroxyl, alcoholic hydroxyl, ketone and quinoid (Russo, and Berlyn, 1990). Humic substances are well known as stimulators of plant germination and growth (Dell'Amico et al., 1994). It was also reported that humic acid application positively affected the plant parameters of plant grown in salinity condition (Türkmen et al., 2005). Humic substances used for plant nutrition, enhance root, plant growth and seed yield.

However, humic acid had significant impact on plant height, number of branchs, dry weight and yield of basil. Humic acid increase root growth by increasing cell elongation or root cell membrane permeability therefore increased water and nutrients uptake by increase root surface area, so improving plant growth, development and carbohydrates content (Said-Al Ahl et al., 2016).

The objective of this study was to improve growth, productivity and oil production as well as chemical composition of M. longifolia L. plant by using humic acid under saline water irrigation conditions in North Sinai region.

\section{MATERIALS AND METHODS}

The present study was carried out on $M$. longifolia L. Fam. Lamiaceae (Labiatae) at the Farm of North Sinai Research Station Desert Research Center, $30 \mathrm{Km}$ East ElArish City (North Sinai Governorate) during the two successive seasons of $2014 / 2015$ and 2015/2016 to improve growth, productivity and oil production as well as chemical composition of $M$. longifolia L. plant by using humic acid under saline water irrigation conditions in North Sinai region.

\section{Plant material and procedure}

6. Saline water at $2048 \mathrm{ppm}+6$ litre.fed $^{-1}$ humic acid.

7. Saline water at $4224 \mathrm{ppm}+$ without humic acid.
8.Saline water at $4224 \mathrm{ppm}+3$ litre.fed $^{-1}$ humic acid.

9. Saline water at $4224 \mathrm{ppm}+6$ litre.fed $^{-1}$ humic acid.

Seedlings of $M$. longifolia L. were obtained from North Sinai Research Station - Desert Research Center, North Sinai Governorate. Homogenous seedlings of 12$15 \mathrm{~cm}$ height were transplanted to the field on $26^{\text {th }}$ April 2014 and $30^{\text {th }}$ April 2015 at distances of $40 \mathrm{~cm}$ between hills (one plant/hill) and $100 \mathrm{~cm}$ between rows (at 10500 plants/fed.). Organic fertilizer (compost) was added as basic dose for two experiments at the rate of $15 \mathrm{~m}^{3}$ per fed. Drip irrigation system was applied in the whole experiment using droppers $\left(41 . \mathrm{h}^{-1}\right)$ for one hour every 2 days, using water salinity at $2048 \mathrm{ppm}$.

\section{Soil and water analyses}

Some mechanical and chemical characteristics of the soil at the experimental site are tabulated in Table 1. The soil samples representing the experiment area was taken at 0-30 cm depth. The water analysis (the second and third levels of water salinity) is shown in Table 2. taken from the irrigation weels water sample was used from North Sinai Station, but, the first level (tap water) was taken from the company of drinking water in El-Sheikh Zwaid.

\section{Water salinity and humic acid treatments}

The Treatments were included the following:

1. Tap water + without humic acid.

2. Tap water +3 litre. fed $^{-1}$ humic acid.

3. Tap water +6 litre.fed $^{-1}$ humic acid.

4. Saline water at $2048 \mathrm{ppm}+$ without humic acid.

5. Saline water at $2048 \mathrm{ppm}+3$ litre.fad. $^{-1}$ humic acid. 
SINAI Journal of Applied Sciences (ISSN: 2314-6079) Vol. (6) Is. (2), Aug. 2017

Table (1): Some initial chemical and physical characteristics of experimental farm soil at 0-30 cm depth.

\begin{tabular}{|c|c|c|c|c|c|c|c|c|c|c|c|}
\hline \multicolumn{12}{|c|}{ Chemical analysis } \\
\hline \multicolumn{4}{|c|}{ Cations (meq. ${ }^{-1}$ ) } & \multicolumn{4}{|c|}{ Anions (meq. ${ }^{-1}$ ) } & \multirow{2}{*}{$\begin{array}{c}\mathrm{ECe} \\
\left(\mathrm{d} . \mathrm{Sm}^{-1}\right)\end{array}$} & \multirow{2}{*}{$\mathbf{p H}$} & \multirow{2}{*}{$\begin{array}{c}\text { Organic } \\
\text { matter } \\
(\%)\end{array}$} & \multirow{2}{*}{$\begin{array}{l}\mathrm{CaCO}_{3} \\
\left(\mathrm{~g} . \mathrm{kg}^{-1}\right)\end{array}$} \\
\hline $\mathbf{C a}^{++}$ & $\mathbf{M g}^{++}$ & $\mathbf{N a}^{+}$ & $\mathbf{K}^{+}$ & $\mathrm{Cl}^{-}$ & $\mathrm{Co}_{3}^{--}$ & $\mathrm{Hco}_{3}^{-}$ & $\mathrm{So}_{4}{ }^{--}$ & & & & \\
\hline 1.04 & 0.35 & 1.56 & 0.17 & 1.05 & - & 0.87 & 1.20 & 0.31 & 7.81 & 0.023 & 1.45 \\
\hline \multicolumn{12}{|c|}{ Mechanical analysis } \\
\hline \multicolumn{3}{|c|}{ Clay } & \multicolumn{2}{|c|}{ Silt } & \multicolumn{3}{|c|}{ Fine sand } & \multicolumn{2}{|c|}{ Coarse sand } & \multicolumn{2}{|c|}{ Soil texture } \\
\hline \multicolumn{3}{|c|}{$2.64(\%)$} & \multicolumn{2}{|c|}{$1.45(\%)$} & \multicolumn{3}{|c|}{$95.61(\%)$} & \multicolumn{2}{|c|}{$0.30(\%)$} & \multicolumn{2}{|c|}{ Sandy soil } \\
\hline
\end{tabular}

Table (2): Some initial chemical and physical characteristics of irrigation water.

\begin{tabular}{|c|c|c|c|c|c|c|c|c|c|c|c|}
\hline \multirow{2}{*}{$\begin{array}{c}\text { Water } \\
\text { Treatmen1 }\end{array}$} & \multirow{2}{*}{$\begin{array}{c}\text { EC } \\
\left(\mathrm{dS} . \mathrm{m}^{-1}\right)\end{array}$} & \multirow{2}{*}{$\begin{array}{c}\mathrm{EC} \\
(\mathrm{ppm})\end{array}$} & \multirow{2}{*}{ pH. } & \multicolumn{4}{|c|}{ Cations (meq..$^{-1}$ ) } & \multicolumn{4}{|c|}{ Anions (meq..$^{-1}$ ) } \\
\hline & & & & $\mathrm{Ca}^{++}$ & $\mathbf{M g}^{++}$ & $\mathrm{Na}^{+}$ & $\mathbf{K}^{+}$ & $\mathrm{CO}_{3}^{-}$ & $\mathrm{HCO}_{3}$ & $\mathrm{Cl}^{-}$ & $\mathrm{SO}_{4}^{-}$ \\
\hline $\mathrm{S}_{1}$ & 1.10 & 704 & 7.4 & 5.40 & 1.60 & 3.28 & 0.42 & - & 4.0 & 3.0 & 3.7 \\
\hline $\mathrm{S}_{2}$ & 3.20 & 2048 & 7.8 & 6.60 & 5.50 & 19.95 & 0.21 & - & 4.5 & 20.0 & 7.2 \\
\hline $\mathrm{S}_{3}$ & 6.60 & 4224 & 7.8 & 10.80 & 6.00 & 35.20 & 0.29 & - & 3.5 & 37.59 & 11.2 \\
\hline
\end{tabular}

$\mathrm{S}_{1}=$ Tap water, $\mathrm{S}_{2}=$ Saline water at $2048 \mathrm{ppm}, \mathrm{S}_{3}=$ Saline water at $4224 \mathrm{ppm}$.

Humic acid as a liquid was obtained from seed outlet in Agricultural Research Center, Giza, Egypt, "Super Canada" produced by the Egyptian Canadian for Humate Trade and Agricultural Consultancies in Egypt, its content from humic acid active $8 \%$, folic acid active $1 \%$, other organic materials $72.3 \%$ and neutral $\mathrm{pH}$. Humic acid added with water irrigation system, it was added for 8 times started from 45 days after planting date and repeated every 15 days.

\section{Statistical analysis}

The layout of this experiment was split plot design with three replications, since water salinity levels were assigned to the main plots, while humic acid concentrations were arranged in the sub-plots. All collected data were analyzed with analysis of variance (ANOVA) procedure using MSTAT-C statistical software package
(Michigan state University, 1983). Differences between means were compared by using Duncan multiple range test at 0.05 (Duncan, 1955).

\section{Observations and Measurements}

\section{Vegetative Growth measurements}

a) Plant height $(\mathrm{cm})$.

b) Number of branches per plant.

c) Herb fresh weight/plant (g).

d) Herb dry weight/plant (g).

Vield perplant $(\mathrm{ml})=\frac{\text { oil percentage } \times \text { Herb dry weight }}{100}$

Yield and oil yield measurements

Oil yield per plant was calculated as follows oilyield per feddan $(\mathrm{L})=,{ }^{\text {illyield }} /$ plant $\times$ mumber of plants.Fed $d^{-1}$

Determination of oil yield per feddan (L.) was calculated as follows Gas 
chromatography-mass spectrometry (GCMS) analysis.

The chemical composition of the samples were performed using Trace GC 1310-ISQ mass spectrometer (Thermo Scientific, Austin, TX, USA) with a direct capillary column TG-35MS (30 m x $0.25 \mathrm{~mm} \times 0.25$ $\mu \mathrm{m}$ film thickness). The column oven temperature was initially held at $55^{\circ} \mathrm{C}$ and then increased by $5^{\circ} \mathrm{C} / \mathrm{min}$ to $300^{\circ} \mathrm{C}$ with hold $5 \mathrm{~min}$. The injector temperature were kept at $250^{\circ} \mathrm{C}$. Helium was used as a carrier gas at a constant flow rate of $1 \mathrm{ml} / \mathrm{min}$. The solvent delay was $2 \mathrm{~min}$ and diluted samples of $1 \mu \mathrm{l}$ were injected automatically using Autosampler AS3000 coupled with $\mathrm{GC}$ in the split mode. Mass spectra were collected at $70 \mathrm{eV}$ ionization voltages over the range of $\mathrm{m} / \mathrm{z} 50-650$ in full scan mode. The ion source and transfer line temperatures were set at 200 and $300^{\circ} \mathrm{C}$, respectively. The components were identified by comparison of their retention times and mass spectra with those of WILEY 09 and NIST 11 mass spectral database.

\section{RESULTS AND DISCUSSION}

\section{Vegetative growth parameters}

As for the interaction effect between water salinity stress and humic acid on some vegetative growth parameters on Mentha longifolia L., results in Table 3 show that the vegetative growth parameters (plant height, number of branches per plant, plant fresh and dry weights) were decreased by increasing water salinity level under low concentration of humic acid. It can concluded that irrigation with tap water and fertilizing with humic acid at 6 1.fed $^{-1}$ significantly increased all vegetative growth parameters and recorded the highest values of plant height, number of branches/plant and plant fresh and dry weights, during first either for first cut $(67.40 \mathrm{~cm}, 44.93,234.07 \mathrm{~g}$ and $88.12 \mathrm{~g}$, respectively) or second cut $(69.97 \mathrm{~cm}$, 46.03, 243.17g and 94.20g, respectively). Also, similar result were obtained during second season either for first cut $(66.67 \mathrm{~cm}$, 45.27, $235.56 \mathrm{~g}$ and $90.96 \mathrm{~g}$, respectively) or second cut $(75.77 \mathrm{~cm}, 50.21,237.64 \mathrm{~g}$ and $91.03 \mathrm{~g}$, respectively).

These results are similar to those found by Hendawy et al. (2015) who evaluated the response of Mintha piperita var. citrata to foliar fertilization under Egyptian conditions. They sprayed the plants with aqueous solution of the test nutrient compounds humic acid (0.2.5 and 5 g.1) and amino spot (0,1 and $1.5 \mathrm{ml})$.observed that, humic acid and/or amino spot fertilizer (Algae extract) had a significant effect on growth characters during both cuts. They demonstrated that there was a clear significantly positive trend in increasing growth characters by spraying of humic acid.

Generally, the decrease in vegetative growth parameters (plant height, number of branches per plant, plant fresh and dry weights) during the two seasons salinity stress may be attributed to several factors. The decline in dry weight in response to increased salinity may be attributed to a combination of osmotic and specific ion effects of $\mathrm{Cl}$ and $\mathrm{Na}$. Also, Moradi and Zavareh (2013) on chickpea stated that plant dry weight was decreased with increasing salinity. The reduction in plant growth under saline conditions may either be due to decrease in the availability of water or increase in sodium chloride toxicity which associated with increasing salinity. Growth inhibition by salt stress also occurs due to the diversion of energy from growth to the maintenance. Munns (2002) reported that the reduction in dry weight of cotton tissues reach to $60 \%$ under salt stress conditions. 
Table (3): Interaction effect between water salinity stress and humic acid on Mentha longifolia L. vegetative growth parameters during 2014-2015 and 2015-2016 seasons.

\begin{tabular}{|c|c|c|c|c|c|c|c|c|c|}
\hline \multirow{2}{*}{$\begin{array}{l}\text { Salinity } \\
\text { levels }\end{array}$} & \multirow{2}{*}{$\begin{array}{l}\text { Humic } \\
\text { conc. }\end{array}$} & \multicolumn{2}{|c|}{$\begin{array}{c}\text { Plant height } \\
(\mathrm{cm})\end{array}$} & \multicolumn{2}{|c|}{$\begin{array}{c}\text { Number of branches } \\
\text { /plant }\end{array}$} & \multicolumn{2}{|c|}{$\begin{array}{c}\text { Herb fresh weight /plant } \\
\text { (g) }\end{array}$} & \multicolumn{2}{|c|}{$\begin{array}{c}\text { Herb dry weight /plant } \\
\text { (g) }\end{array}$} \\
\hline & & $2014 / 2015$ & $2015 / 2016$ & $2014 / 2015$ & $2015 / 2016$ & $2014 / 2015$ & $2015 / 2016$ & $2014 / 2015$ & $2015 / 2016$ \\
\hline \multicolumn{10}{|c|}{ First cut } \\
\hline \multirow{3}{*}{$\mathbf{S}_{1}$} & $\mathbf{H}_{\mathbf{0}}$ & $51.87 \mathrm{~cd}$ & $50.53 \mathrm{e}$ & $27.53 \mathrm{de}$ & $28.33 \mathrm{ef}$ & $137.41 \mathrm{e}$ & $127.78 \mathrm{c}-\mathrm{e}$ & $51.52 \mathrm{~g}$ & $49.45 \mathrm{~cd}$ \\
\hline & $\mathbf{H}_{1}$ & $61.67 \mathrm{~b}$ & $63.13 \mathrm{~b}$ & $39.73 \mathrm{~b}$ & $42.07 \mathrm{ab}$ & $226.30 \mathrm{ab}$ & $219.89 \mathrm{ab}$ & $80.04 \mathrm{~b}$ & $80.39 \mathrm{ab}$ \\
\hline & $\mathbf{H}_{2}$ & $67.40 \mathrm{a}$ & $66.67 \mathrm{a}$ & $44.93 \mathrm{a}$ & $45.27 \mathrm{a}$ & $234.07 \mathrm{a}$ & $235.56 \mathrm{a}$ & $88.12 \mathrm{a}$ & $90.69 \mathrm{a}$ \\
\hline \multirow{3}{*}{$\mathbf{S}_{2}$} & $\mathbf{H}_{\mathbf{0}}$ & $47.87 \mathrm{ef}$ & $46.67 \mathrm{f}$ & $25.67 \mathrm{ef}$ & $26.33 \mathrm{ef}$ & $119.26 \mathrm{f}$ & $116.67 \mathrm{de}$ & $44.31 \mathrm{~h}$ & $44.97 \mathrm{~cd}$ \\
\hline & $\mathbf{H}_{1}$ & $52.00 \mathrm{~cd}$ & $53.93 \mathrm{~d}$ & $30.27 \mathrm{~d}$ & $34.93 \mathrm{~cd}$ & $206.67 \mathrm{c}$ & $201.11 \mathrm{~b}$ & $70.96 \mathrm{~d}$ & $73.74 \mathrm{~b}$ \\
\hline & $\mathbf{H}_{2}$ & $54.60 \mathrm{c}$ & $57.27 \mathrm{c}$ & $35.47 \mathrm{c}$ & $38.40 \mathrm{bc}$ & $216.67 \mathrm{~b}$ & $214.44 \mathrm{ab}$ & $75.42 \mathrm{c}$ & $76.54 \mathrm{ab}$ \\
\hline \multirow{3}{*}{$\mathbf{S}_{\mathbf{3}}$} & $\mathbf{H}_{0}$ & $39.80 \mathrm{~g}$ & $40.13 \mathrm{~g}$ & $20.73 \mathrm{~g}$ & $22.53 \mathrm{f}$ & $95.00 \mathrm{~g}$ & $100.56 \mathrm{e}$ & $36.69 \mathrm{i}$ & $37.87 \mathrm{~d}$ \\
\hline & $\mathbf{H}_{1}$ & $45.13 \mathrm{f}$ & $48.27 \mathrm{ef}$ & $23.53 \mathrm{fg}$ & $28.27 \mathrm{ef}$ & $142.22 \mathrm{e}$ & $136.67 \mathrm{~cd}$ & $58.41 \mathrm{f}$ & $52.96 \mathrm{c}$ \\
\hline & $\mathbf{H}_{2}$ & $50.53 \mathrm{de}$ & $49.67 \mathrm{ef}$ & $27.60 \mathrm{de}$ & $29.53 \mathrm{de}$ & $151.48 \mathrm{~d}$ & $153.89 \mathrm{c}$ & $62.47 \mathrm{e}$ & $58.22 \mathrm{c}$ \\
\hline \multicolumn{10}{|c|}{ Second cut } \\
\hline \multirow{3}{*}{$\mathbf{S}_{1}$} & $\mathbf{H}_{\mathbf{0}}$ & $49.30 \mathrm{ef}$ & $52.42 \mathrm{~d}$ & $28.50 \mathrm{~d}$ & $30.04 \mathrm{de}$ & $141.80 \mathrm{f}$ & $135.69 \mathrm{f}$ & $58.62 \mathrm{f}$ & $53.23 \mathrm{ef}$ \\
\hline & $\mathbf{H}_{1}$ & $63.63 \mathrm{~b}$ & $66.44 \mathrm{~b}$ & $41.73 \mathrm{~b}$ & $43.39 b$ & $232.57 \mathrm{~b}$ & $226.30 \mathrm{~b}$ & $91.94 \mathrm{~b}$ & $84.15 \mathrm{ab}$ \\
\hline & $\mathbf{H}_{2}$ & $69.97 \mathrm{a}$ & $75.77 \mathrm{a}$ & $46.03 \mathrm{a}$ & $50.21 \mathrm{a}$ & $243.17 \mathrm{a}$ & $237.64 \mathrm{a}$ & $94.20 \mathrm{a}$ & $91.03 \mathrm{a}$ \\
\hline \multirow{3}{*}{$\mathbf{S}_{2}$} & $\mathbf{H}_{\mathbf{0}}$ & $46.13 \mathrm{~g}$ & $48.04 \mathrm{e}$ & $26.77 \mathrm{~d}$ & $27.59 \mathrm{e}$ & $123.72 \mathrm{~g}$ & $119.92 \mathrm{~g}$ & $53.73 \mathrm{~g}$ & $47.68 \mathrm{f}$ \\
\hline & $\mathbf{H}_{1}$ & $54.33 \mathrm{~d}$ & $58.26 \mathrm{c}$ & $34.30 \mathrm{c}$ & $37.42 \mathrm{c}$ & $210.46 \mathrm{~d}$ & $206.11 \mathrm{~d}$ & $78.52 \mathrm{~d}$ & $74.44 \mathrm{c}$ \\
\hline & $\mathbf{H}_{2}$ & $57.33 \mathrm{c}$ & $64.40 \mathrm{~b}$ & $38.47 \mathrm{~b}$ & $42.35 \mathrm{~b}$ & $223.70 \mathrm{c}$ & $218.31 \mathrm{c}$ & $89.88 \mathrm{c}$ & $80.65 \mathrm{bc}$ \\
\hline \multirow{3}{*}{$\mathbf{S}_{3}$} & $\mathbf{H}_{\mathbf{0}}$ & $40.27 \mathrm{~h}$ & $42.06 \mathrm{f}$ & $22.60 \mathrm{e}$ & $23.72 \mathrm{f}$ & $90.34 \mathrm{~h}$ & $102.69 \mathrm{~h}$ & $37.60 \mathrm{~h}$ & $37.42 \mathrm{~g}$ \\
\hline & $\mathbf{H}_{1}$ & $48.33 \mathrm{fg}$ & $49.79 \mathrm{de}$ & $26.43 \mathrm{~d}$ & $29.43 \mathrm{de}$ & $144.32 \mathrm{f}$ & $141.09 \mathrm{f}$ & $59.14 \mathrm{f}$ & $56.87 \mathrm{de}$ \\
\hline & $\mathbf{H}_{2}$ & $51.40 \mathrm{e}$ & $51.44 \mathrm{de}$ & $29.60 \mathrm{~d}$ & $32.21 \mathrm{~d}$ & $155.12 \mathrm{e}$ & $156.62 \mathrm{e}$ & $62.44 \mathrm{e}$ & $62.20 \mathrm{~d}$ \\
\hline
\end{tabular}

Means followed by the same letter(s) within each column are not significantly different at the 0.05 level, according to Duncan's multiple range test.

$\mathbf{S}_{1}$ : Tap water, $\mathbf{S}_{2}$ : Water salinity at $2048 \mathrm{ppm}, \mathbf{S}_{3}:$ Water salinity at $4224 \mathrm{ppm}, \mathbf{H}_{\mathbf{0}}:$ Without humic acid, $\mathbf{H}_{\mathbf{1}}:\left(3\right.$ 1.fed $\left.{ }^{-1}\right)$ humic acid, $\mathbf{H}_{2}:\left(61 . f e d^{-1}\right)$ humic acid. 
It can be concluded that under water stress, turgor pressure decreased and closure of stomata takes place causing decreased photosynthesis (Gale and Zeroni, 1984). Ionic toxicity of $\mathrm{Na}^{+}$and $\mathrm{Cl}^{-}$ is considered to be the other reason for decreasing shoot fresh weight with increasing salinity (Bhatti et al., 1983; Ibrahim, 2003).

Also, Boris et al. (2010) concluded that humic substances provided a bio-stimulating effect on growth of cucumber. In this respect, physiological mechanisms through which humic substances exert their effects may depend on hormones and, in particular, on the presence of auxin or auxin like components in their structure and, consequently its effect on plant growth and development (Eyheraguibel et al., 2008).

Accordingly, Chen et al. (2004) pointed that the direct effects of humic substances depends on biochemical actions on cell wall, membrane or cytoplasm, mainly hormonal acting, in manner similar to plant growth substances (Kaya et al., 2005) and agricultural humic substances are reputed to drought tolerance, enhance nutrient uptake and overall plant performance resulting in increasing leaf area and biomass production, so this was in agreement with the findings of the present work.

Moreover, Mora et al. (2010) mentioned that, the ability of humic substances to increase shoot growth in different plant species cultivated under diverse growth conditions might be attributed to $\mathrm{H}+$ ATPase activity and nitrate root-shoot distribution that, in turn, causes changes in the root-shoot distribution of certain cytokinins, polyamines and abscisic acid, thus affecting shoot growth.

\section{Yield and oil yield measurements}

Regarding the response of fresh herb yield/fed, dry herb yield /fed, Essential oil percentage, Essential oil per plant and Content plant Essential oil yield per feddan to the interaction effect between water salinity levels and humic acid concentrations, results of Table 4 reveal that in most cases the low water salinity (tap water) with adding humic acid at 6 l.fed $^{-1}$ treatment caused the maximum significant increases in fresh herb yield/fed, dry herb yield/fed, Essential oil percentage, Essential oil per plant and content plant essential oil yield per feddan (2457.78 kg.fed ${ }^{-1}, 925.26 \mathrm{~kg} \mathrm{fed}^{-1}, 4.93 \%$, $4.346 \mathrm{ml}$ and 45.633 L.fed $\left.^{-1}\right)$ and (2473.33 kg.fed ${ }^{-1}, 952.23$ kg.fed ${ }^{-1}, 4.89 \%, 4.436 \mathrm{ml}$ and 46.578 L.fed $^{-1}$ ) for the first cut, and (2553.33 kg.fed ${ }^{-1}, 989.08$ kg.fed $^{-1}, 4.64 \%$, $4.372 \mathrm{ml}$ and 45.906 L.fed $\left.^{-1}\right)$ and $(2495.19$ kg.fed ${ }^{-1}, 955.86 \mathrm{~kg} \mathrm{fed}^{-1}, 4.61 \%, 4.197 \mathrm{ml}$ and $44.068 \mathrm{~L} . f e d^{-1}$ ) for the second cut, in both seasons, respectively, followed by low water salinity (tap water) with adding humic acid at 3 l.fed $^{-1}$ treatment, in the two cuts during both seasons. While, high salinity water without humic acid treatment had the least values in this concern.

On the other hand, other interactions induced intermediate values. These results are in agreement with those reported by Massoud et al. (2010) on Marjoram (Majorana hortensis) plant, since they showed that essential oil percentage was greatly influenced by level of field capacity and using of humic acid. Hence, at the three cuts in the two seasons, treating the plants of marjoram with humic acid at the level of $100 \%$ field capacity had enhancing effect on oil formation of herb.

\section{Analysis of Mentha longifolia volatile oil components by GC-MS}

Results represented in Table 5 show the results obtained by using Gas chromatography/mass spectrometry (GCMS) analysis for two treatments. These selected treatments are $\mathrm{S}_{1} \mathrm{H}_{2}$ treatment, which caused the highest volatile oil percentage, and $\mathrm{S}_{3} \mathrm{H}_{0}$ treatment, which achived the lowest volatile oil percentage. The samples of the essential oil during the first cut in the second season and subjected to GC-MS analysis. 
Table (4): Effect of saline water irrigation, humic acid and their interactions on herb yield and oil production of Mentha longifolia L. during 2014-2015 and 2015-2016 seasons.

\begin{tabular}{|c|c|c|c|c|c|c|c|c|c|c|c|}
\hline \multirow[t]{2}{*}{ Salinity T. } & \multirow[t]{2}{*}{ Humic T. } & \multicolumn{2}{|c|}{$\begin{array}{l}\text { Fresh herb yield } \\
\text { (kg/fed.) }\end{array}$} & \multicolumn{2}{|c|}{$\begin{array}{l}\text { Dry herb yield } \\
\text { (kg/fed.) }\end{array}$} & \multicolumn{2}{|c|}{$\begin{array}{l}\text { Essential oil } \\
(\%)\end{array}$} & \multicolumn{2}{|c|}{$\begin{array}{l}\text { Essential oil } \\
\quad(\mathrm{ml})\end{array}$} & \multicolumn{2}{|c|}{$\begin{array}{l}\text { Essential oil yield } \\
\text { (L.fed.) }\end{array}$} \\
\hline & & $2014 / 2015$ & $2015 / 2016$ & $2014 / 2015$ & $2015 / 2016$ & $2014 / 2015$ & $2015 / 2016$ & $2014 / 2015$ & $2015 / 2016$ & $2014 / 2015$ & $2015 / 2016$ \\
\hline \multicolumn{12}{|c|}{ First cut } \\
\hline \multirow{4}{*}{$\mathbf{S}_{1}$} & $\mathbf{H}_{\mathbf{0}}$ & $1442.78 \mathrm{e}$ & $1341.67 \mathrm{c}-\mathrm{e}$ & $541.00 \mathrm{~g}$ & $519.24 \mathrm{~cd}$ & $2.54 \mathrm{f}$ & $2.86 \mathrm{de}$ & $1.308 \mathrm{~g}$ & $1.416 \mathrm{de}$ & $13.73 \mathrm{~g}$ & $14.87 \mathrm{de}$ \\
\hline & $\mathbf{H}_{1}$ & $2376.11 \mathrm{ab}$ & $2308.83 \mathrm{ab}$ & $840.42 \mathrm{~b}$ & $844.05 \mathrm{ab}$ & $4.78 \mathrm{a}$ & $4.55 b$ & $3.823 \mathrm{~b}$ & $3.658 \mathrm{ab}$ & $40.14 \mathrm{~b}$ & $38.41 \mathrm{ab}$ \\
\hline & $\mathbf{H}_{2}$ & $2457.78 \mathrm{a}$ & $2473.33 \mathrm{a}$ & $925.26 \mathrm{a}$ & $952.23 \mathrm{a}$ & $4.93 \mathrm{a}$ & $4.89 \mathrm{a}$ & $4.346 \mathrm{a}$ & $4.436 \mathrm{a}$ & $45.63 \mathrm{a}$ & $46.58 \mathrm{a}$ \\
\hline & $\mathbf{H}_{\mathbf{0}}$ & $1252.22 \mathrm{f}$ & $1225.00 \mathrm{de}$ & $465.23 \mathrm{~h}$ & $472.22 \mathrm{~cd}$ & $2.19 \mathrm{~g}$ & $2.39 \mathrm{e}$ & $0.971 \mathrm{~h}$ & $1.073 \mathrm{de}$ & $10.19 \mathrm{~h}$ & $11.27 \mathrm{de}$ \\
\hline \multirow[t]{3}{*}{$\mathbf{S}_{\mathbf{2}}$} & $\mathbf{H}_{1}$ & $2170.00 \mathrm{c}$ & $2111.67 \mathrm{~b}$ & $745.05 \mathrm{~d}$ & $774.27 \mathrm{~b}$ & $3.78 \mathrm{c}$ & $4.05 \mathrm{bc}$ & $2.685 \mathrm{~d}$ & $2.987 \mathrm{bc}$ & $28.19 \mathrm{~d}$ & $31.36 \mathrm{bc}$ \\
\hline & $\mathbf{H}_{2}$ & $2275.00 \mathrm{~b}$ & $2251.67 \mathrm{ab}$ & $791.93 \mathrm{c}$ & $803.69 \mathrm{ab}$ & $4.37 \mathrm{~b}$ & $4.59 \mathrm{bc}$ & $3.299 \mathrm{c}$ & $3.510 \mathrm{ab}$ & $34.64 \mathrm{c}$ & $36.86 \mathrm{ab}$ \\
\hline & $\mathbf{H}_{\mathbf{0}}$ & $997.50 \mathrm{~g}$ & $1055.83 \mathrm{e}$ & $385.27 \mathrm{i}$ & $397.61 \mathrm{~d}$ & $2.05 \mathrm{~g}$ & $2.20 \mathrm{e}$ & $0.753 \mathrm{i}$ & $0.832 \mathrm{e}$ & $7.91 \mathrm{i}$ & $8.74 \mathrm{e}$ \\
\hline \multirow[t]{3}{*}{$\mathbf{S}_{3}$} & $\mathbf{H}_{1}$ & $1493.33 \mathrm{e}$ & $1435.00 \mathrm{~cd}$ & $613.35 \mathrm{f}$ & $556.10 \mathrm{c}$ & $2.73 \mathrm{e}$ & $3.08 \mathrm{de}$ & $1.592 \mathrm{f}$ & $1.629 \mathrm{de}$ & $16.72 \mathrm{f}$ & $17.10 \mathrm{de}$ \\
\hline & $\mathbf{H}_{2}$ & $1590.56 \mathrm{~d}$ & $1615.83 \mathrm{c}$ & $655.95 \mathrm{e}$ & $611.35 \mathrm{c}$ & $3.14 \mathrm{~d}$ & $3.77 \mathrm{~cd}$ & $1.962 \mathrm{e}$ & $2.196 \mathrm{~cd}$ & $20.60 \mathrm{e}$ & $23.06 \mathrm{~cd}$ \\
\hline & \multicolumn{11}{|c|}{ Second cut } \\
\hline \multirow{4}{*}{$\mathbf{S}_{1}$} & $\mathbf{H}_{\mathbf{0}}$ & $1488.90 \mathrm{f}$ & $1424.82 f$ & $615.46 \mathrm{f}$ & 558.95 ef & $2.29 \mathrm{ef}$ & $2.45 \mathrm{de}$ & $1.340 \mathrm{f}$ & $1.303 \mathrm{~d}-\mathrm{f}$ & $14.07 \mathrm{f}$ & $13.68 \mathrm{~d}-\mathrm{f}$ \\
\hline & $\mathbf{H}_{1}$ & $2442.02 \mathrm{~b}$ & $2376.12 \mathrm{~b}$ & $965.42 \mathrm{~b}$ & $883.61 \mathrm{ab}$ & $4.02 \mathrm{~b}$ & $4.15 \mathrm{~b}$ & $3.692 \mathrm{~b}$ & $3.489 \mathrm{~b}$ & $38.766 \mathrm{~b}$ & $36.63 \mathrm{~b}$ \\
\hline & $\mathbf{H}_{2}$ & $2553.33 \mathrm{a}$ & $2495.19 \mathrm{a}$ & $989.08 \mathrm{a}$ & $955.86 \mathrm{a}$ & $4.64 \mathrm{a}$ & $4.61 \mathrm{a}$ & $4.372 \mathrm{a}$ & $4.197 \mathrm{a}$ & $45.906 \mathrm{a}$ & $44.07 \mathrm{a}$ \\
\hline & $\mathbf{H}_{\mathbf{0}}$ & $1299.03 \mathrm{~g}$ & $1259.11 \mathrm{~g}$ & $564.19 \mathrm{~g}$ & $500.59 \mathrm{f}$ & $2.12 \mathrm{fg}$ & $2.15 \mathrm{e}$ & $1.138 \mathrm{~g}$ & 1.024 ef & $11.949 \mathrm{~g}$ & 10.75 ef \\
\hline \multirow[t]{3}{*}{$\mathbf{S}_{\mathbf{2}}$} & $\mathbf{H}_{1}$ & $2209.87 \mathrm{~d}$ & $2164.20 \mathrm{~d}$ & $824.41 \mathrm{~d}$ & $781.62 \mathrm{c}$ & $2.67 \mathrm{~d}$ & $3.72 \mathrm{~b}$ & $2.095 \mathrm{~d}$ & $2.772 \mathrm{c}$ & $21.997 \mathrm{~d}$ & $29.11 \mathrm{c}$ \\
\hline & $\mathbf{H}_{2}$ & $2348.89 \mathrm{c}$ & 2292.22 c & $943.69 \mathrm{c}$ & $846.79 \mathrm{bc}$ & $3.78 \mathrm{c}$ & $3.98 \mathrm{~b}$ & $3.393 \mathrm{c}$ & $3.208 \mathrm{bc}$ & $35.626 \mathrm{c}$ & $33.68 \mathrm{bc}$ \\
\hline & $\mathbf{H}_{\mathbf{0}}$ & $948.54 \mathrm{~h}$ & $1001.04 \mathrm{~h}$ & $394.77 \mathrm{~h}$ & $392.90 \mathrm{~g}$ & $2.01 \mathrm{~g}$ & $2.00 \mathrm{e}$ & $0.754 \mathrm{~h}$ & $0.750 \mathrm{f}$ & $7.917 \mathrm{~h}$ & $7.88 \mathrm{f}$ \\
\hline \multirow[t]{2}{*}{$\mathbf{S}_{3}$} & $\mathbf{H}_{1}$ & $1515.41 \mathrm{f}$ & $1481.45 \mathrm{f}$ & $620.96 \mathrm{f}$ & $597.17 \mathrm{de}$ & $2.44 \mathrm{e}$ & $2.69 \mathrm{~cd}$ & $1.444 \mathrm{f}$ & $1.532 \mathrm{de}$ & $15.162 \mathrm{f}$ & $16.09 \mathrm{de}$ \\
\hline & $\mathbf{H}_{2}$ & $1628.71 \mathrm{e}$ & $1644.52 \mathrm{e}$ & $655.64 \mathrm{e}$ & $653.05 \mathrm{~d}$ & $2.87 \mathrm{~d}$ & $3.11 \mathrm{c}$ & $1.793 \mathrm{e}$ & $1.933 \mathrm{~d}$ & $18.827 \mathrm{e}$ & $20.29 \mathrm{~d}$ \\
\hline
\end{tabular}

Means followed by the same letter(s) within each column are not significantly different at the 0.05 level, according to Duncan's multiple range test.

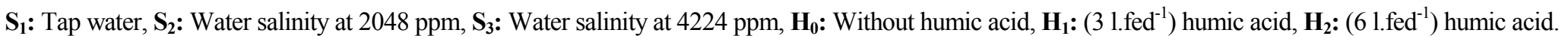


Table (5): Effect of water salinity and humic acid on chemical composition of Mentha longifolia volatile oil using GC-MS.

\begin{tabular}{|c|c|c|c|}
\hline No. & Compound name & $\mathbf{S}_{1} \mathbf{H}_{2}$ & $\mathbf{S}_{3} \mathbf{H}_{0}$ \\
\hline 1 & $\alpha$-Pinene & $\mathbf{1 . 0 3}$ & 0.91 \\
\hline 2 & Camphene & 0.04 & - \\
\hline 3 & Sabinene & 0.80 & 0.75 \\
\hline 4 & p-Pinene & 1.70 & 1.64 \\
\hline 5 & $\alpha$-Myrcene & 0.17 & 0.08 \\
\hline 6 & D-Limonene & 0.35 & 0.20 \\
\hline 7 & 1,8-Cineole & 15.02 & 18.95 \\
\hline 8 & trans Sabinene hydrate & 0.09 & - \\
\hline 9 & 2-Cyclohexen-1-ol,1-methyl-4-(1-methylethyl)-, cis- & - & 0.07 \\
\hline 10 & cis-Sabinol & 0.27 & 0.23 \\
\hline 11 & cis-Verbenol & 0.15 & 0.14 \\
\hline 12 & Menthone & 30.20 & 27.93 \\
\hline 13 & Linalyl propionate & 0.33 & - \\
\hline 14 & 3-Cyclohexene-1-methanol,à,à,4-trimethyl-, (S)- (CAS) & - & 0.62 \\
\hline 15 & Isopulegone & 0.81 & 1.20 \\
\hline 16 & 3-Cyclohexen-1-ol,4-methyl-1-(1-methylethyl)- (CAS) & - & 0.95 \\
\hline 17 & $\alpha$-Terpineol & 1.18 & $\mathbf{1 . 7 5}$ \\
\hline 18 & 1-Eicosanol (CAS) & - & 0.35 \\
\hline 19 & 1-Dodecanol, 3,7,11-trimethyl- & - & 0.09 \\
\hline 20 & Bicyclo[3.1.1]hept-3-en-2-one,4,6,6-trimethyl- & 0.07 & - \\
\hline 21 & Cyclohexanone,2-isopropyl-2,5-dimethyl- & 0.17 & - \\
\hline 22 & Pulegone & 46.01 & 39.92 \\
\hline 23 & $\alpha$-Terpinyl propionate & - & 0.26 \\
\hline 24 & p-Cymen-3-ol & - & 0.61 \\
\hline 25 & Myrtenyl acetate & 0.05 & - \\
\hline 26 & 1-Cyclohexanone,2-methyl-2-(3-methyl-2-oxobutyl) & 0.04 & - \\
\hline 27 & 4-(2,2,6-Trimethyl-bicyclo[4.1.0]hept-1-yl)-butan-2-one & 0.02 & - \\
\hline 28 & 2-Cyclohexen-1-one,3-methyl-6-(1-methylethylidene)-(CAS) & 0.05 & - \\
\hline 29 & Caryophyllene & 0.21 & 0.14 \\
\hline 30 & ç-Muurolene & 0.10 & - \\
\hline 31 & ç-Cadinene (CAS) & - & 0.12 \\
\hline 32 & Caryophyllene oxide & 0.51 & 0.79 \\
\hline 33 & 2,5,9-Trimethylcycloundeca-4,8-dienone & - & 0.09 \\
\hline 34 & Cubenol & 0.04 & 0.08 \\
\hline 35 & ë-Cadinene (CAS) & 0.45 & 0.71 \\
\hline 36 & 1H-Dibenzo[a,i]fluorene, eicosahydro- & - & 0.19 \\
\hline 37 & Arteannuin b & 0.06 & - \\
\hline \multicolumn{2}{|c|}{ Total } & 99.92 & 98.77 \\
\hline
\end{tabular}


It can be showed that, 37 compounds were identified were collected the major component was pulegone followed by menthone, 1,8-Cineole, $p$-Pinene, $\alpha$-Pinene, $\alpha$-Terpineol and isopulegone. These components represent $95.95-92.30 \%$ of wild mint oil extracted from both treatment.

It can be seen that with $\mathrm{S}_{1} \mathrm{H}_{2}$ treatment, the major component of oil was pulegone (46.01\%), followed by menthone $(30.20 \%)$, 1,8-Cineole $(15.02 \%)$, p-Pinene $(1.70 \%)$, $\alpha$-Terpineol (1.18\%), $\alpha$-Pinene $(1.03 \%)$ and isopulegone $(0.81 \%)$.

While, when wild mint plants were treated by $\mathrm{S}_{3} \mathrm{H}_{0}$ treatment, the major component was pulegone (39.92\%), followed by menthone $(27.93 \%)$, 1,8-Cineole (18.95\%), $\alpha$-Terpineol (1.75 $\%)$, p-Pinene $(1.64 \%)$, isopulegone (1.20 $\%)$ and $\alpha$-Pinene $(0.91 \%)$.

\section{REFERENCES}

Alarcon, J.J.; Sanchez-Blanco, M.J.; Bolardn, M.C. and Torrecillas, A. (1993). Water relations and osmotic adjustment in Lycopersicon esculentum and $L$. pennellii during short term salt exposure and recovery. Physiologia Plantarum, 89: 441-447.

Bhatti, A.S.; Sarwar, G.; Wieneke, J. and Tahir, M. (1983). Salt effects on growth and mineral contents of Diplachne fusca (Kallar grass). J. Plant Nutr., 6 (3): 293 254.

Boris, P.; Eyheraguibel, B.; Morard, M. and Silvestre, J. (2010). Direct effects of humic-like substance on growth, water and mineral nutrition of various species. J. Plant Nutr., 34: 46-59.

Chen, Y.; De Nobili, M. and Aviad, T. (2004). Stimulatory effects of humic substances on plant growth, p. 131-165. In: Magdoff, F. and R. Weil (Eds.). Soil Organic Matter in Sustainable Agric. CRC Press, Boca Raton, FL, USA.
Dell'Amico, C.; Masciandaro, G.; Ganni, A.; Ceccanti, B.; García, C.; Hernández, T. and Costa, F. (1994). Effects of specific humic fractions on plant growth. In: Humic Substances in the Global Environment and Implications on Human Health. Senesi, N. and Miano, T.M. (eds.) Elsevier Science. Amsterdam, Netherlands, 563566.

Duncan, B.D. (1955). Multiple Range and Multiple F-tests. Biometrics, 11: 1- 42.

Eyheraguibel, B.; Silvestre, J. and Morard, P. (2008). Effects of humic substances derived from organic waste enhancement on the growth and mineral nutrition of maize. Bioresour. Technol. 99: 4206-4212.

Franco, J.A.; Ferngndez, J.A.; Banon, S. and Gonzgles, A. (1997). Relationship between the effects of salinity on seedling leaf area and fruit yield of six muskmelons cultivars. Hort. Sci., 32: 642-647.

Gale, J. and Zeroni, M. (1984). Cultivation of plants in brackish water in controlled environment agriculture. pp: 363-380. In: Staples, R. C. and G. H. Thoenniessen (Eds.). Salinity Tolerance in Plants, Strategies for Crop Improvement, John Wiley and Sons, New York, 151-170.

Hendawy, S.F.; Hussein, M.S.; El-Gohary, A.E. and Ibrahim, M.E. (2015). Effect of foliar organic fertilization on the growth, yield and oil content of Mentha piperita var. citrate. Asian J. Agric. Res., 9 (5): 237-248.

Ibrahim, M. (2003). Salt tolerance studies on cotton. MSc. (Hons.) Thesis Inst. Soil and Environ. Sci., Univ. Agric., Faisalabad, 88.

Kaya, M.; Atak, M.; Mahmood, K.; Cefci, C.Y. and Ozcan, S. (2005). Effect of pre-sowing seed treatment with zinc and foliar spray of humic acid on 
yield of common bean (Phaseolus vulgaris L.). Int. J. Agric. Biol., 7: 875878.

Maas, E.V. (1990). Crop salt tolerance. In: K. K. Tanji (ed.), Agricultural Salinity Assessment and Management. ASCE Manual and Reports on Engineering Practice No. 71, Ame. Soc. Civil Engineers, New York, NY., 262-304.

Massoud, H.Y.; Abdalah, M.Y.A.; Mosa, A.A.A. and Nour Eldeen, E.A.E. (2010). Effect of water stress and folair spray of humic acid on growth and essential oil quality of marjoram (Majorana hortensis moench) plant. J. Plant Prod., Mansoura Univ., 1(8): 11131123.

Matsuda, K. and Riazi, A. (1981). Stressinduced osmotic adjustment in growing regions of barley leaves. Plant Physiol., 68: 571-576.

Michigan State University (1983). MSTAT-C micro-computer Statistical Program, Version 2. Michigan State Univ., USA.

Mora, V.; Bacaicoa, E.; Zamarreño, A.M.; Aguirre, E.; Garnica, M.; Fuentes, M. and García-Mina, J.M. (2010). Action of humic acid on promotion of cucumber shoot growth involves nitrate-related changes associated with the root-to-shoot distribution of cytokinins, polyamines and mineral nutrients. J. Plant. Physiol., 167: 633-642.

Moradi, P. and Zavareh, M. (2013). Effects of salinity on germination and early seedling growth of chickpea (Cicer arietinum L.) cultivars. Int. J. Farming and Allied Sci., 2(3): 70-74.
Munns, R. (2002). Comparative physiology of salt and water stress. Plant Cell and Environ., 25: 239-250.

Munns, R. and Tester, M. (2008). Mechanisms of salinity tolerance. Ann. Review Plant Biol., 59: 651-681.

Parida, A.K. and Das, A.B. (2005). Salt tolerance and salinity effects on plants: a review. Ecotoxicol. and Environ., Safety 60: 324-349.

Russo, R.O. and Berlyn, G.P. (1990). The use of organic biostimulants to help low input sustainable agriculture. J. Sustainable Agric., 1 (2): 19-42.

Said-AlAhl, H.A.H.; El-Gendy, A.G. and Omer, E.A. (2016). Humic Acid and indole acetic acid affect yield and essential oil of dill grown under two different locations in Egypt. J. Pharm. Sci. and Res., 8 (7): 594-606.

Shannon, M.C. and Grieve, C.M. (1999). Tolerance of vegetable crops to salinity. Scientia Horticulturae 78: 5-38.

Shannon, M.C.; Grieve, C.M. and Francois, L.E. (1994). Whole plant response to salinity. In: Plant Environment Interactions (Ed.): R.E. Wilkinson. Marcel Dekker, New York, 199-244.

Sher, Z. and Khan, Z.D. (2007). Floristic composition, life form and leaf spectra of the vegetation of Chagharzai Valley, District Buner. Pak. J. Plant Sci., 13(1): 57-66.

Türkmen, Ö.; Demir, S.; Ensoy, S. and Dursun, A. (2005). Effects of mycorrhizal fungus and humic acid on the seedling development and nutrient content of pepper grown under saline soil conditions. J. Biol. Sci., 5 (5): 568574. 


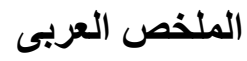

تحسـين إنتاجـية نباتات الحـبق باستخـــام حامـض الهيوميك تحــت ظـروف الـري بالميــاه المالحـة

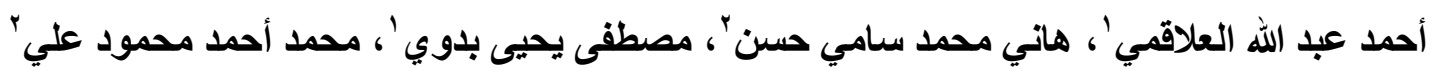

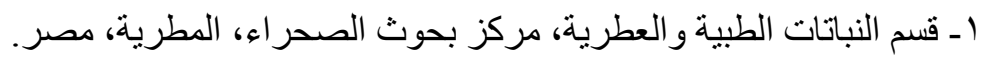
rـ قسم الإنتاج النباتي، كلية العلوم الزر اعية البيئية، جامعة العريش، مصر.

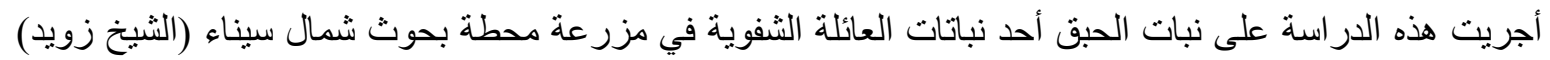

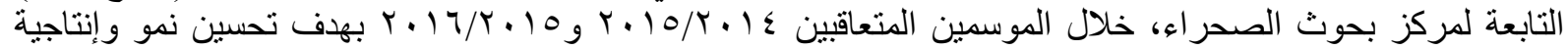

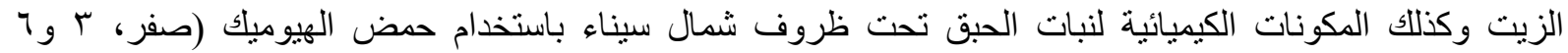

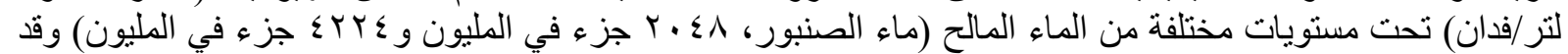

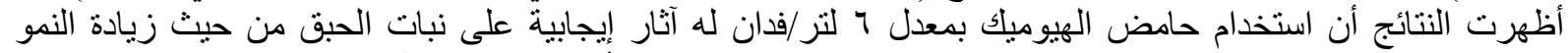

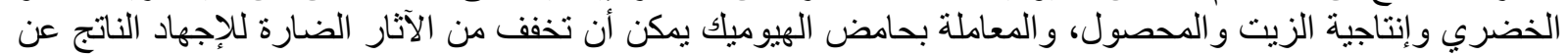

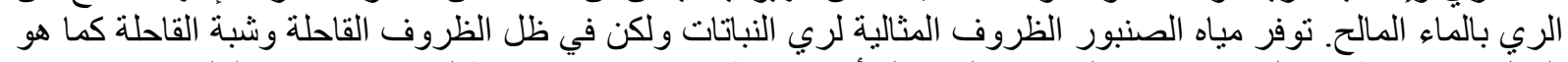

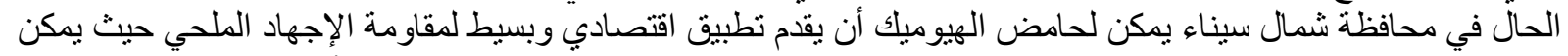

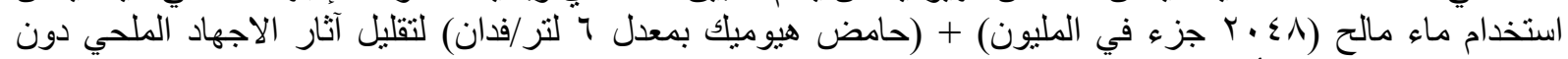
إنخفاض في المحصول أو إنتاج الزيت. الكلمات الإسترشادية: إنتاجية، نباتات الحبق، حامض الهيو التيوميك، الري بالمياه المالحة. 
